\title{
Functional characterization of hyperpolarization-activated cyclic nucleotide-gated channels in rat pancreatic $\beta$ cells
}

\author{
Yi Zhang ${ }^{1, *}$, Yunfeng Liu' ${ }^{1, *}$, Jihong Qu ${ }^{2}$, Alexandre Hardy ${ }^{1}$, Nina Zhang ${ }^{1,3}$, Jingyu Diao ${ }^{1}$, Paul J Strijbos ${ }^{4}$, \\ Robert Tsushima1, Richard B Robinson ${ }^{2}$, Herbert Y Gaisano1, Qinghua Wang ${ }^{1,3}$ and Michael B Wheeler ${ }^{1}$ \\ ${ }^{1}$ Departments of Physiology and Medicine, University of Toronto, Room 7310, Medical Sciences Building, 1 King's College Circle, Toronto, Ontario, Canada \\ M5S 1 A8 \\ ${ }^{2}$ Department of Pharmacology, Columbia University, New York, New York 10032, USA \\ ${ }^{3}$ Division of Endocrinology and Metabolism, Li Ka-Shing Knowledge Institute, St Michael's Hospital, Room 7005, Queen Wing, 30 Bond Street, Toronto, \\ Ontario, Canada M5B 1W8 \\ ${ }^{4}$ Neurology and GI Centre of Excellence for Drug Discovery, GlaxoSmithKline, New Frontiers Science Park, Harlow CM19 5AW, UK \\ (Correspondence should be addressed to Y Zhang; Email: zany.zhang@utoronto.ca; Q Wang; Email: qinghua.wang@utoronto.ca) \\ *(Y Zhang and Y Liu contributed equally to this work)
}

\begin{abstract}
Hyperpolarization-activated cyclic nucleotide-gated ( $\mathrm{HCN})$ channels regulate pacemaker activity in some cardiac cells and neurons. In the present study, we have identified the presence of HCN channels in pancreatic $\beta$-cells. We then examined the functional characterization of these channels in $\beta$-cells via modulating HCN channel activity genetically and pharmacologically. Voltage-clamp experiments showed that over-expression of HCN2 in rat $\beta$-cells significantly increased HCN current $\left(I_{\mathrm{h}}\right)$, whereas expression of dominant-negative HCN2 (HCN2-AYA) completely suppressed endogenous $I_{\mathrm{h}}$. Compared to control $\beta$-cells, overexpression of $I_{\mathrm{h}}$ increased insulin secretion at $2.8 \mathrm{mmol} / \mathrm{l}$ glucose. However, suppression of $I_{\mathrm{h}}$ did not affect insulin secretion at both 2.8 and $11.1 \mathrm{mmol} / 1$ glucose.
\end{abstract}

Current-clamp measurements revealed that HCN2 overexpression significantly reduced $\beta$-cell membrane input resistance $\left(R_{\text {in }}\right)$, and resulted in a less-hyperpolarizing membrane response to the currents injected into the cell. Conversely, dominant negative HCN2-AYA expression led to a substantial increase of $R_{\mathrm{in}}$, which was associated with a more hyperpolarizing membrane response to the currents injected. Remarkably, under low extracellular potassium conditions $\left(2.5 \mathrm{mmol} / 1 \mathrm{~K}^{+}\right)$, suppression of $I_{\mathrm{h}}$ resulted in increased membrane hyperpolarization and decreased insulin secretion. We conclude that $I_{\mathrm{h}}$ in $\beta$-cells possess the potential to modulate $\beta$-cell membrane potential and insulin secretion under hypokalemic conditions.

Journal of Endocrinology (2009) 203, 45-53

\section{Introduction}

The current produced by hyperpolarization-activated cyclic nucleotide-gated $(\mathrm{HCN})$ channels, termed $I_{\mathrm{h}}$, has been recorded in a variety of cardiac cells and neurons. Unlike most voltage-dependent channels, HCN channels are activated by membrane hyperpolarization and are permeable to both $\mathrm{Na}^{+}$and $\mathrm{K}^{+}$ions. To date, four mammalian $\mathrm{HCN}$ isoforms (HCN1-4) have been cloned. A major function of $I_{\mathrm{h}}$ is to serve as a pacemaker current in some excitable cells (DiFrancesco 1993, Robinson \& Siegelbaum 2003). This pacemaker function is believed to play important roles in regulating heart rate and spontaneous electrical activity of neurons. In pyramidal neuron dendrites (Poolos et al. 2002), amacrine cells (Koizumi et al. 2004) and thalamocortical relay neurons (Meuth et al. 2006), $I_{\mathrm{h}}$ has been proposed to participate in controlling and stabilizing resting membrane potential. $I_{\mathrm{h}}$ has also been thought to be involved in the responses to sour taste, neuronal plasticity, and dendritic integration (reviewed in Pape (1996), Robinson \& Siegelbaum (2003) and Wahl-Schott \& Biel (2009)).

Pancreatic $\beta$-cells are electrically excitable cells that secrete insulin to maintain blood glucose homeostasis. A number of ion channels contribute to this function. Among these channels, the ATP-sensitive $\mathrm{K}^{+}\left(\mathrm{K}_{\mathrm{ATP}}\right)$ channel initiates membrane depolarization at high glucose and the voltagedependent $\mathrm{Ca}^{2+}$ channel plays a key role for action potential firing and insulin secretion (Rorsman et al. 1994). We had reported that voltage-dependent $\mathrm{K}^{+}(\mathrm{Kv})$ channels are involved in the repolarization phase of the action potential; and that blockade of the $\mathrm{Kv}$ channel prolongs the action potential duration and enhances insulin secretion (MacDonald et al. 2002, MacDonald \& Wheeler 2003). Recently, we demonstrated the presence of an HCN-encoded $I_{\mathrm{h}}$ in the pancreatic $\beta$-cell (El Kholy et al. 2007). In the present study, we further examine its functional characterization in regulation of electrical activity of pancreatic $\beta$-cells. 


\section{Materials and Methods}

\section{Islet isolation and cell culture}

Islets of Langerhans were isolated from male Wistar rats weighing $250-350 \mathrm{~g}$ by collagenase digestion and separated by density gradient centrifugation, as described previously (MacDonald et al. 2001). Animal procedures were performed in accordance with the University of Toronto's Animal Care Committee's ethical guidelines. To obtain single islet cells, the intact rat islets were dispersed in dispase II solution (Roche) at $37{ }^{\circ} \mathrm{C}$ for $5 \mathrm{~min}$ and the single cells were plated on glass coverslips. Intact islets or dispersed islet cells were cultured in RPMI 1640 medium containing $11.1 \mathrm{mmol} / 1$ glucose supplemented with $10 \%$ fetal bovine serum, $10 \mathrm{mmol} / 1$ HEPES, 100 units $/ \mathrm{ml}$ penicillin, and $100 \mu \mathrm{g} / \mathrm{ml}$ streptomycin for $24-72 \mathrm{~h}$ before experiments.

\section{Immunostaining and fluorescence confocal microscopy}

Cells were fixed with $4 \%$ paraformaldehyde in PBS for 15 min and permeabilized with $0 \cdot 2 \%$ Triton X-100 in PBS at room temperature for $10 \mathrm{~min}$. Cells were then incubated with blocking solution containing $5 \% \mathrm{BSA}$ and $0 \cdot 1 \%$ Triton X-100 in PBS at $37^{\circ} \mathrm{C}$ for $30 \mathrm{~min}$ or $4{ }^{\circ} \mathrm{C}$ for overnight. Subsequently, cells were co-incubated with anti-HCN $(1: 100,1: 100,1: 100$ or $1: 2000$ for anti-HCN-1, HCN-2, HCN-3 or HCN-4, respectively) and anti-insulin (Dako, Glostrup, Denmark; 1:1000) primary antibodies for $16 \mathrm{~h}$ at $4{ }^{\circ} \mathrm{C}$. HCN antibodies were generated as previously described (Xiao et al. 2004). After washing, cells were stained with fluorescein-conjugated secondary antibodies. The coverslips were mounted with ProLong Gold antifade reagent (Invitrogen). Confocal laser scanning microscopy images analysis was performed using a Zeiss LSM-510 imaging system (Carl Zeiss, Oberkochen, Germany).

\section{Adenoviral infection}

We created an adenovirus expressing murine HCN2 (AdIRES-hrGFP-mHCN2) using the AdMax pdc516 shuttle vector (Microbix Biosystems, Toronto, ON, Canada) as previously described ( $\mathrm{Qu}$ et al. 2001), and incorporating green fluorescent protein (GFP) under the control of an IRES (Stratagene, La Jolla, CA, USA). We similarly created the Ad-IRES-hrGFP-mHCN2-AYA adenovirus, expressing a previously characterized (Er et al. 2003) dominant negative HCN2 construct in which the signature pore motif $\left(\mathrm{GYG}_{402-404}\right)$ of $\mathrm{mHCN} 2$ is mutated to AYA. For control experiments, an adenoviral GFP vector was used. Islet cells were transduced as previously described $(\mathrm{Qu}$ et al. 2001, Er et al. 2003). The multiplicity of infection (ratio of viral units to cells) was 100-150. The islets or cells were incubated in infection medium containing the adenoviruses for $2-3 \mathrm{~h}$ at $37^{\circ} \mathrm{C}$, after which the medium was replaced with culture medium and further cultured for $48-72 \mathrm{~h}$ before experiments. Under these conditions, the infection efficiency was routinely $80-90 \%$ as determined by GFP expression.

\section{Western blotting analysis}

Expression of HCN2 proteins in rat islets adenovirally infected were determined by western blot. Rat brain was used as a positive control. Cell lysates $(25 \mu \mathrm{g})$ were subjected to SDS-PAGE and transferred to polyvinylidene difluoride-plus membranes (Fisher Scientific Ltd, Nepean, ON, Canada). Membranes were probed with the antibody for HCN2 (1:800 dilution). The bound primary antibody was detected with peroxidase-conjugated secondary antirabbit antibody (1:30 000; Jackson ImmunoResearch Laboratories, West Grove, PA, USA) and visualized by chemiluminescence (ECL-Plus, GE Healthcare, Mississauga, ON, Canada).

\section{Electrophysiology}

Cells were patch-clamped in perforated whole-cell configuration at $33-34{ }^{\circ} \mathrm{C}$. $\beta$-Cells were identified by cell size $(>4 \mathrm{pF})$ and their depolarization response to $11.1 \mathrm{mmol} / \mathrm{l}$ glucose (Wendt et al. 2004, Manning Fox et al. 2006). The measurements were performed using EPC-9 amplifier and PULSE software from HEKA Electronik (Lambrecht, Germany). Patch pipettes were pulled from $1.5 \mathrm{~mm}$ thin-walled borosilicate glass tubes using a two-stage Narishige micropipette puller (Narishige Co., Tokyo, Japan). The pipettes had typical resistances of 3-6 M $\Omega$ when fire polished and filled with an intracellular solution containing $140 \mathrm{mmol} / 1 \mathrm{KCl}$; $1 \mathrm{mmol} / 1 \mathrm{MgCl}_{2} ; 0.05 \mathrm{mmol} / 1$ EGTA; $10 \mathrm{mmol} / 1 \mathrm{NaCl}$; $10 \mathrm{mmol} / 1$ HEPES; pH $7 \cdot 3$ adjusted with $\mathrm{KOH}$. Gramicidin was added to the intracellular solution to a final concentration of $60 \mu \mathrm{g} / \mathrm{ml}$ immediately before the experiment. Standard extracellular solutions contained $138 \mathrm{mmol} / 1 \mathrm{NaCl} ; 5.6 \mathrm{mmol} / 1 \mathrm{KCl} ; 1.2 \mathrm{mmol} / 1 \mathrm{MgCl}_{2}$; $2.6 \mathrm{mmol} / 1 \mathrm{CaCl}_{2} ; 5 \mathrm{mmol} / 1 \mathrm{HEPES} ; 11.1 \mathrm{mmol} / \mathrm{l} \mathrm{glu}-$ cose; $\mathrm{pH} 7.4$ adjusted with $\mathrm{NaOH}$. For membrane potential recordings in Fig. 1, $2.8 \mathrm{mmol} / 1$ glucose was also used. For the low potassium extracellular solution used in Fig. 2, $138 \mathrm{mmol} / 1 \mathrm{NaCl}$ and $5.6 \mathrm{mmol} / 1 \mathrm{KCl}$ from standard extracellular solution were replaced by $140 \mathrm{mmol} / 1 \mathrm{NaCl}$ and $2.5 \mathrm{mmol} / 1 \mathrm{KCl}$. All perforated patch recordings were achieved with serial resistance below $25 \mathrm{M} \Omega$, and leak subtraction protocol was not applied. In current-clamp mode, membrane potential responses were measured from whole rat islets. The membrane input resistance $\left(R_{\text {in }}\right)$ was estimated by Ohm's law $R_{\text {in }}=U / I$, where $U$ is the membrane voltage measured at the end of current (I) injection. The equilibrium potential for potassium $\left(E_{\mathrm{K}}\right)$ was calculated by Nernst equation. ZD7288 was purchased from Tocris (Ellisville, MO, USA). 

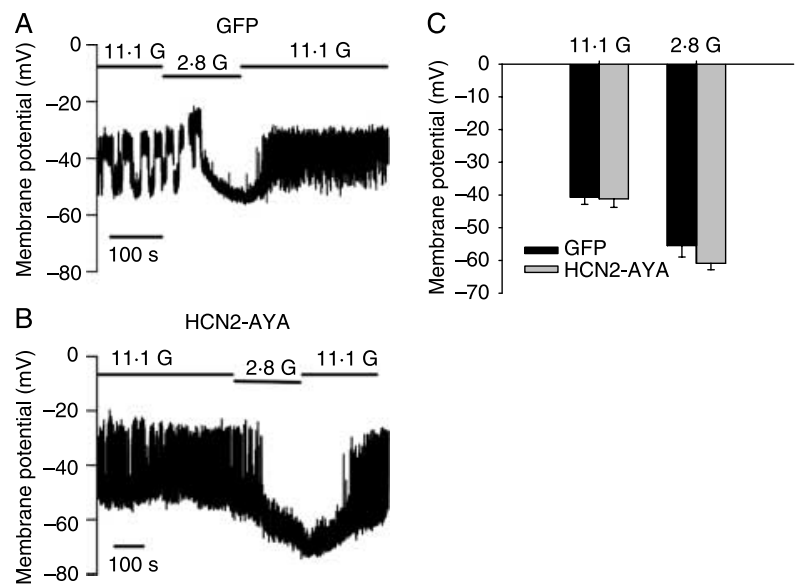

Figure 1 Influence of $I_{\mathrm{h}}$ on membrane potential in standard extracellular solution containing $5.6 \mathrm{mmol} / \mathrm{I} \mathrm{KCl}$ : membrane potentials were recorded without current injection in rat islet $\beta$-cells transduced with (A) GFP or (B) HCN2-AYA in the presence of $11 \cdot 1 \mathrm{mmol} / \mathrm{l}(11 \cdot 1 \mathrm{G})$ and $2 \cdot 8 \mathrm{mmol} / \mathrm{l}(2 \cdot 8 \mathrm{G})$ glucose. (C) Summary of mean membrane potentials at $11 \cdot 1$ and $2.8 \mathrm{mmol} / \mathrm{l}$ glucose ( $n=5$ for each).

\section{Static insulin secretion assay}

After $72 \mathrm{~h}$ post-infection, the islets (10/vial) were preincubated with glucose free Krebs-Ringer HEPES buffer (KRB, $125 \mathrm{mmol} / 1 \mathrm{NaCl}, 5.6 \mathrm{mmol} / \mathrm{K} \mathrm{KCl}, 1 \cdot 28 \mathrm{mmol} / 1$ $\mathrm{CaCl}_{2}, 5 \cdot 0 \mathrm{mmol} / 1 \mathrm{NaCO}_{3}, 25 \mathrm{mmol} / 1 \mathrm{HEPES}$, and $0 \cdot 1 \%$ $(\mathrm{w} / \mathrm{v}) \mathrm{BSA}$ ) for $30 \mathrm{~min}$, followed by incubation with 2.8 or $11.1 \mathrm{mmol} / 1$ glucose in KRB for $90-\mathrm{min}$. The supernatants of the islets were collected and centrifuged at $300 \mathrm{~g}$ for $10 \mathrm{~min}$ to remove cell debris and insulin was measured by RIA (Dai et al. 2006). The islets were then used for cell viability assessment. The insulin secretion data were normalized by the islet cell viability via an XTT absorbance assay. The XTT cell proliferation assay (Proliferation Kit II; Roche Applied Sciences) was performed according to the manufacturer's instructions and as we have previously shown (Targonsky et al.
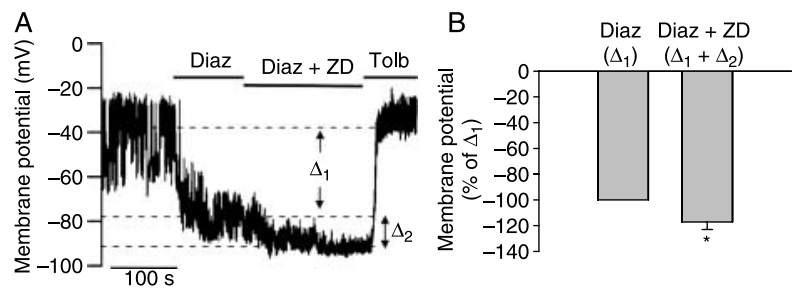

Figure 2 Influence of $I_{\mathrm{h}}$ on membrane hyperpolarization in extracellular solution containing $2.5 \mathrm{mmol} / \mathrm{KCl}$ : membrane potentials were recorded without current injection. (A) Rat islet $\beta$-cells were perfused with solution containing $11 \cdot 1 \mathrm{mmol} / \mathrm{l}$ glucose and were then challenged with $200 \mu \mathrm{M}$ diazoxide (Diaz) in the absence or presence of $50 \mu \mathrm{M}$ ZD7288 (ZD) followed by perfusion of $300 \mu \mathrm{M}$ tolbutamide (Tolb). (B) Bar graph shows the normalized changes of mean membrane potentials (to $\Delta_{1}$ induced by diazoxide), $\Delta_{2}$ is the excessive change induced by ZD7288 at the presence of diazoxide $(n=6)$. Data shown are mean \pm S.E.M., ${ }^{*} P<0 \cdot 05$ by paired $t$-test.
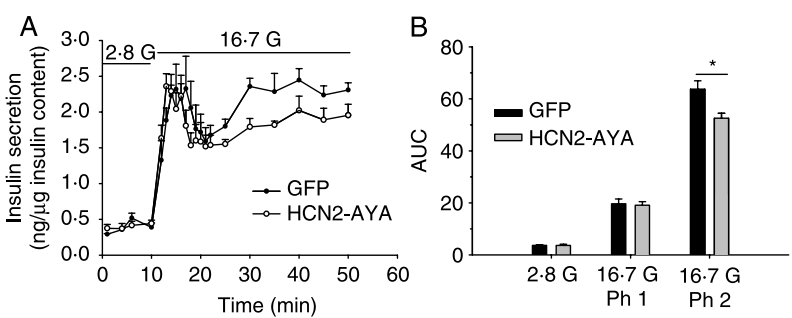

Figure 3 Influence of $I_{\mathrm{h}}$ on insulin secretion in extracellular solution containing $2.5 \mathrm{mmol} / \mathrm{l} \mathrm{KCl}$ : (A) islet perifusion insulin secretion assay was performed and the amount of insulin were measured at $2 \cdot 8 \mathrm{mmol} / \mathrm{l}$ glucose $(2 \cdot 8 \mathrm{G})$ and $16.7 \mathrm{mmol} / /$ glucose $(16 \cdot 7 \mathrm{G})$ as indicated, insulin released was normalized to total insulin content. (B) Average of area under curves (AUC) of insulin levels during islet perifusion from $\mathrm{A}(n=4)$. The first phase (Ph1) of insulin secretion at $16.7 \mathrm{mmol} / \mathrm{l}$ glucose was quantified from 10 to $21 \mathrm{~min}$ and the second phase (Ph2) from 21 to $50 \mathrm{~min}$ from A. Data shown are mean \pm S.E.M., ${ }^{*} P<0 \cdot 05$ compared with GFP control.

2006). Briefly, after insulin secretion experiments, the islets were immediately incubated with the XTT reagent for $6 \mathrm{~h}$ and the absorbance readings at $490 \mathrm{~nm}$ were recorded.

\section{Islet perifusion secretory assay}

After $72 \mathrm{~h}$ post-infection, batches of 50 islets were placed in perifusion chambers with a capacity of $1.3 \mathrm{ml}$ at $37^{\circ} \mathrm{C}$ and perifused with $\mathrm{KRB}$ at a flow rate of $1 \mathrm{ml} / \mathrm{min}$ as described above. For the low potassium extracellular solution used in Fig. 3, $128 \mathrm{mmol} / 1 \mathrm{NaCl}$ and $2.5 \mathrm{mmol} / \mathrm{l} \mathrm{KCl}$ were used to replace the original concentrations of $\mathrm{NaCl}$ and $\mathrm{KCl}$ in the KRB. Islets were stimulated with 2.8 or $16.7 \mathrm{mmol} / 1$ glucose in the presence or absence of Forskolin $(10 \mu \mathrm{M}$, SigmaAldrich Ltd) plus 3-isobutyl-1-methylxanthine (IBMX; $100 \mu \mathrm{M}$, Sigma-Aldrich Ltd) as indicated. Fractions were collected for insulin determination using a RIA kit (Linco Research, St Louis, MO, USA). At the end of each perifusion, islets were collected and lysed in acid ethanol for assessment of insulin content. Results are presented as insulin secreted normalized to total insulin content.

\section{Statistical analysis}

All data are presented as means \pm s.E.M. Statistical analysis was done by Student's $t$-test or paired $t$-test and significance was assumed at a $P$ value of $<0 \cdot 05$. All calculations were made by SigmaPlot (SigmaPlot 2001, SPSS Science, Chicago, IL, USA). Patch clamp data were analysed with IGOR Pro3.12 software (Wavemetrics, Lake Oswego, OR, USA).

\section{Results}

$H C N$ channels are expressed in rat $\beta$-cells

Four members of the $H c n$ gene family $(H c n 1-4)$ are currently known (Santoro et al. 1997, 1998, Ludwig et al. 1998). 
We therefore used specific antibodies of each of these HCN isoforms, which detected the presence of all four $\mathrm{HCN}$ isoforms in primary rat $\beta$-cells (Fig. 4). These results are consistent with our previously reported real-time PCR analysis of rat islet mRNA (El Kholy et al. 2007). Of note, some non- $\beta$-cells (see arrows pointing at non-insulin staining cells) are also positive for $\mathrm{HCN}$, indicating that $\mathrm{HCN}$ channels are also expressed in other types of islet cells (Zhang et al. 2008).

Electrophysiological properties of native $\mathrm{I}_{h}$ in rat $\beta$-cells

We investigated the native $I_{\mathrm{h}}$ in rat $\beta$-cells. As shown in Fig. 5A, hyperpolarizing voltages elicited slow activating inward currents (Fig. 5Aii), while application of $\mathrm{HCN}$ channel blocker, ZD7288 $(50 \mu \mathrm{M})$, inhibited these currents (Fig. 5Aiii). On average, ZD7288 blocked $67 \cdot 9 \pm 7 \cdot 2 \%$ $(P<0 \cdot 01, n=6)$ of the sustained $I_{\mathrm{h}}$ obtained at $-140 \mathrm{mV}$. Since both $\mathrm{Na}^{+}$and $\mathrm{K}^{+}$permeate $\mathrm{HCN}$ channels, the reversal potentials of $I_{\mathrm{h}}$ are between approximately -50 and $-20 \mathrm{mV}$ in many native pacemaker cell types (Pape 1996, Accili et al. 2002). To test the ion selectivity of $I_{\mathrm{h}}$ in rat $\beta$-cells, a current-voltage $(I / V)$ relationship of the fully activated HCN channel was plotted and the reversal potential of $I_{\mathrm{h}}$ was obtained at $-38 \mathrm{mV}$ (Fig. 5Bii and Biii), suggesting that $I_{\mathrm{h}}$ in $\beta$-cells is a mixed cationic current of $\mathrm{Na}^{+}$and $\mathrm{K}^{+}$(Tian \& Shipston 2000). These data clearly showed that native $I_{\mathrm{h}}$ in rat $\beta$-cells possesses

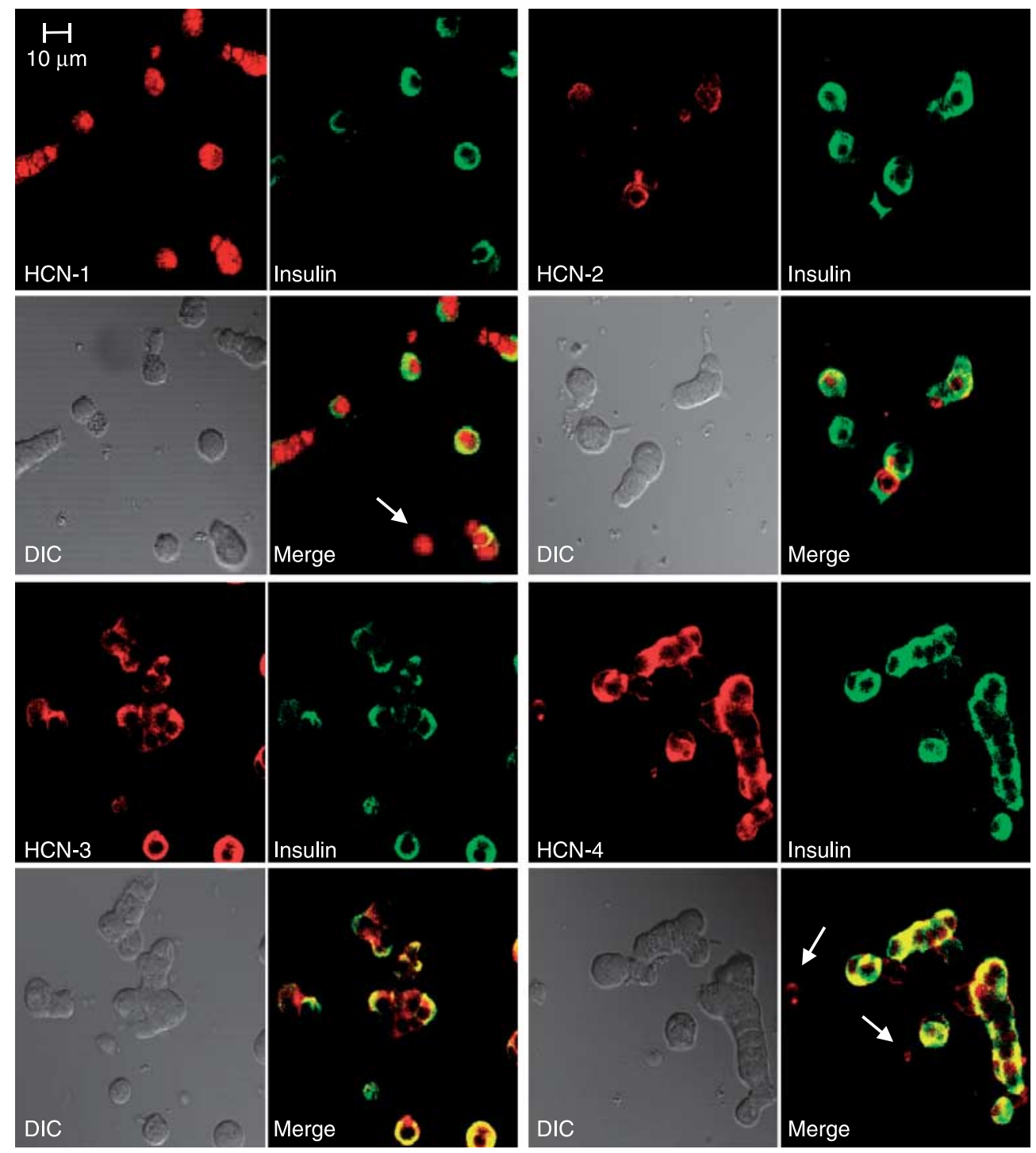

Figure 4 Expression of $\mathrm{HCN}$ proteins in pancreatic rat islet cells: representative confocal laser scanning microscopy images of dispersed rat islet cells, which were dual-stained for each of the HCN isoforms (red) and insulin (green). Light (left) and merged images (right) are shown in the lower panels of each group. 

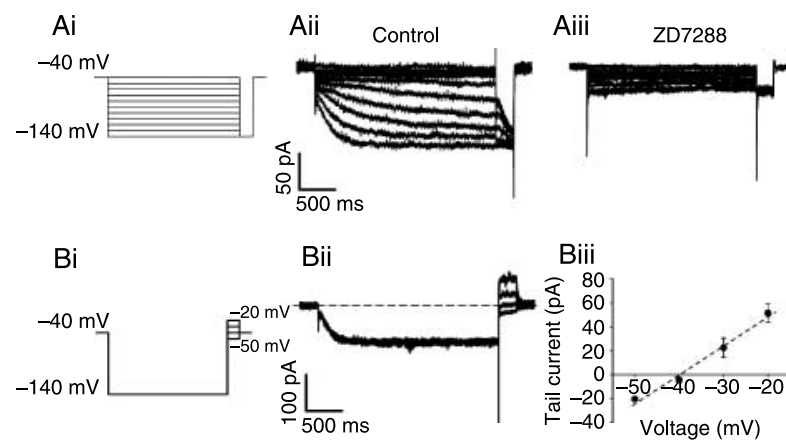

Figure 5 Characteristics of native $l_{\mathrm{h}}$ in rat $\beta$-cells: (A) effect of ZD7288 on $I_{\mathrm{h}}$. Cells were clamped from a holding potential of $-40 \mathrm{mV}$ to various voltages $(-140$ to $-40 \mathrm{mV}$ ) for $2.5 \mathrm{~s}$ followed by a step to $-140 \mathrm{mV}$ (Ai). The slow hyperpolarization-activated $I_{\mathrm{h}}$ currents were induced with this voltage protocol under control conditions (Aii); and ZD7288 $(50 \mu \mathrm{M})$, an $I_{\mathrm{h}}$ inhibitor, blocked $67 \cdot 9 \pm 7 \cdot 2 \%$ of $I_{\mathrm{h}}$ at $-140 \mathrm{mV}(P<0 \cdot 01, n=6$, Aiii).

(B) Determination of current-voltage relationship of the fully activated $\mathrm{HCN}$ channels. To obtain the $I / V$ relationship, a family of $250 \mathrm{~ms}$ test pulses ranging from -70 to $-20 \mathrm{mV}$ were applied to $\beta$-cells after a $2 \cdot 5$-s pre-pulse to $-140 \mathrm{mV}$ ( $\mathrm{Bi}$, voltage protocol). Bii showed the typical series of current traces, the dashed line indicates zero current. The $I / V$ curve was made by plotting tail currents against test potentials (right panel, $n=6$ ) showing the reversal potential is $-38 \mathrm{mV}$ (Biii). Data shown are mean \pm s.E.M.

typical properties of HCN channels as reported in other cell types (Ludwig et al. 1999, Kaupp \& Seifert 2001, Yu et al. 2004).

Effects of over-expression or dominant-negative suppression of HCN channels on $\mathrm{I}_{h}$

In order to investigate the functional role of $I_{\mathrm{h}}$, we employed an adenoviral gene transfer strategy to manipulate HCN channel gene expression and current magnitude in primary $\beta$-cells (Qu et al. 2001). Cells transduced with GFP alone were used as control. Western blotting results show that the level of HCN2 proteins was effectively enhanced after infection (Fig. 6A). Patch-clamp study demonstrates that over-expression of HCN2 in the islet $\beta$-cells resulted in a significant increase in inward currents (Fig. 6Biii) compared with GFP control (Fig. 6Bi). Figure 6C illustrates the voltagedependent $I / V$ relationships of the HCN channel. The mean current density in HCN2-transduced cells was approximately sixteenfold greater than that in control cells at $-140 \mathrm{mV}$ $(66 \pm 9 \mathrm{pA} / \mathrm{pF}$ for HCN2, $n=7 ; 4 \cdot 1 \pm 0.5 \mathrm{pA} / \mathrm{pF}$ for GFP control, $n=6$; $P<0 \cdot 001$ ); in contrast, expression of dominant-negative HCN2-AYA almost completely suppressed endogenous $I_{\mathrm{h}}(0 \cdot 3 \pm 0 \cdot 3 \mathrm{pA} / \mathrm{pF}$ for HCN2-AYA, $n=7$; $P<0 \cdot 001$ versus control, Fig. 6Bii and $\mathrm{C}$ ).

To determine the steady-state activation of these channels, tail currents induced by a $-140 \mathrm{mV}$ pulse were measured and the data were fit using the Boltzmann equation (Yagi \& Sumino 1998). As shown in Fig. 6D, the tail current amplitudes displayed typical sigmoidal properties (Ludwig et al. 1999). The half-maximal activation $\left(V_{1 / 2}\right)$ voltage was $-97 \pm 1 \mathrm{mV}$ in GFP control and $-96 \pm 1 \mathrm{mV}$ in HCN2 group (Fig. 6D).

\section{Influence of $\mathrm{I}_{h}$ on insulin secretion}

Since ion channels play a pivotal role in regulation of insulin secretion, we next sought to determine whether insulin secretion is affected by HCN channel modulation. Our static insulin secretion data show HCN2-over-expression increased insulin secretion at $2.8 \mathrm{mmol} / \mathrm{l}$ glucose, but not change the secretion at $11.1 \mathrm{mmol} / \mathrm{l}$ glucose when compared with GFP control (Fig. 7A and B). No difference was observed for insulin secretion between HCN2-AYA-transduced and GFPtransduced islets at both glucose concentrations (Fig. 7A and $\mathrm{B}$ ). To further confirm the results, we employed islet perifusion to investigate the effect of $\mathrm{HCN}$ channels on dynamic insulin secretion. We find HCN2-AYA did not change the insulin secretion pattern compared to GFP control even in the presence of forskolin/IBMX (Fig. 7C and D).

A
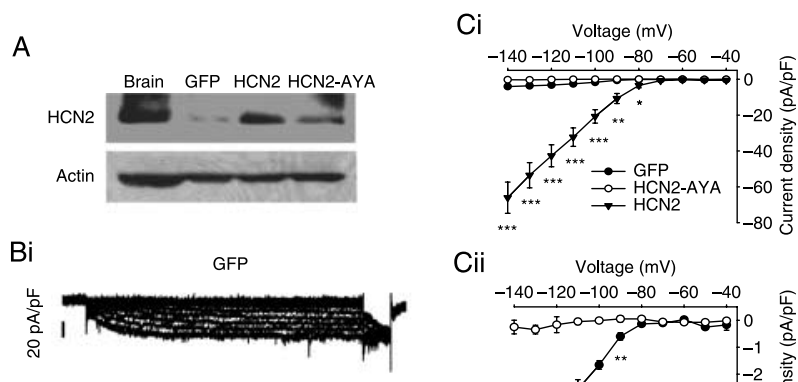

Cii

Voltage $(\mathrm{mV})$
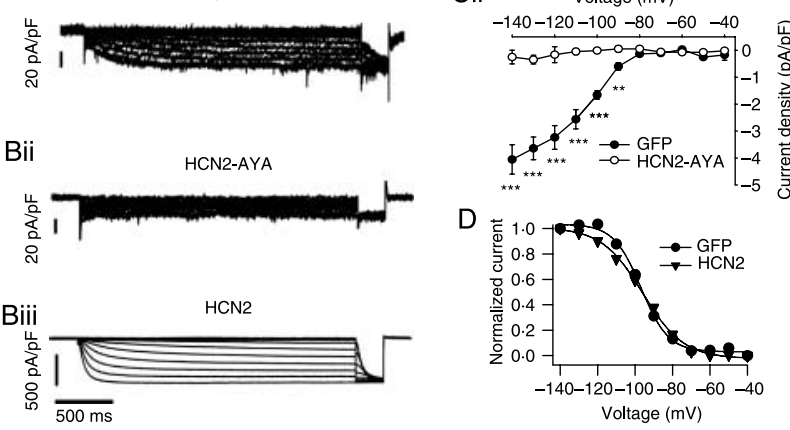

Figure 6 Effects of up-regulation and dominant-negative suppression of $\mathrm{HCN}$ channels on $I_{\mathrm{h}}$ in rat $\beta$-cells: (A) western blotting showing the effect of $\mathrm{HCN} 2$ or HCN2-AYA infection on $\mathrm{HCN} 2$ protein levels in rat islet cells. Rat brain was used as positive control. $\beta$-Actin was examined to assess the protein loading of the lanes. (B) Representative current traces of $l_{\mathrm{h}}$ were recorded in GFP (Bi), HCN2-AYA (Bii) and HCN2-transduced cells (Biii). Different vertical scales were indicated. Voltage protocol was identical in Figs 5A and 6B. (Ci) Steady-state current-voltage relationships were obtained by plotting the sustained inward currents with corresponding test voltages. Cii was the expanded vertical scale of Bi to clearly show the effect of HCN2-AYA on $I_{\mathrm{h}}$ compared to control. (D) Steady-state voltage activation curves of $I_{\mathrm{h}}$ in GFP and HCN2-transduced cells. The tail currents measured immediately after the voltage step to $-140 \mathrm{mV}$ were normalized and fit by the Boltzmann function. The membrane potentials of halfmaximal activation $\left(V_{1 / 2}\right)$ were obtained as $-97 \pm 1 \mathrm{mV}$ in GFP control $(n=6)$ and $-96 \pm 1 \mathrm{mV}$ in HCN2 $(n=6)$, respectively. Data shown are mean \pm S.E.M., ${ }^{*} P<0 \cdot 05,{ }^{* *} P<0.01$ and ${ }^{* * *} P<0.001$, respectively, compared with the control. 

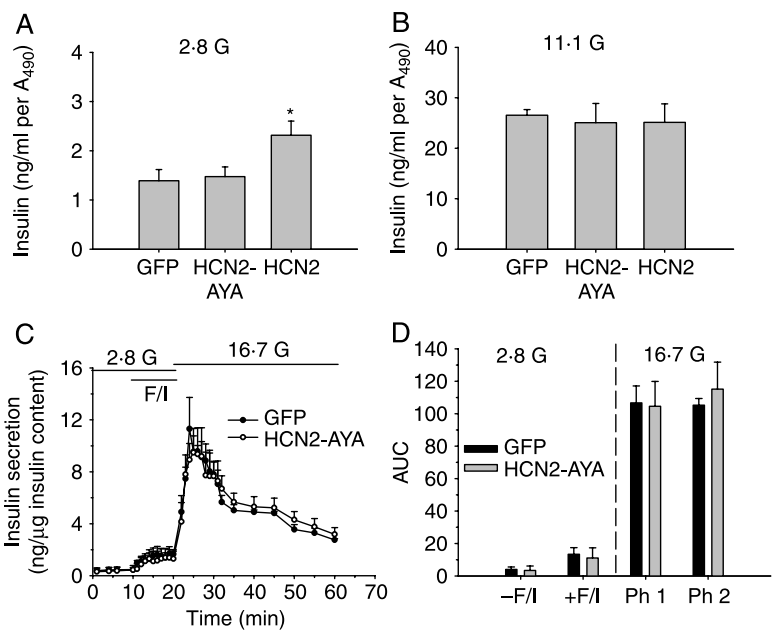

Figure 7 Influence of $I_{\mathrm{h}}$ on insulin secretion: (A and B) the islet static insulin secretion assay was performed and the amount of insulin were measured at $2 \cdot 8 \mathrm{mmol} / \mathrm{l}$ glucose $(2 \cdot 8 \mathrm{G})$ and $11 \cdot 1 \mathrm{mmol} / \mathrm{l}$ glucose $(11 \cdot 1 \mathrm{G})$, data were then normalized to the absorbance from XTT assay $(n=5)$. (C) The islet perifusion insulin secretion assay was performed and the amount of insulin were measured at $2 \cdot 8 \mathrm{mmol} / \mathrm{I}$ glucose $(2 \cdot 8 \mathrm{G})$ and $16.7 \mathrm{mmol} / \mathrm{l}$ glucose $(16.7 \mathrm{G})$ in the presence or absence of forskolin $(10 \mu \mathrm{M})$ plus IBMX $(100 \mu \mathrm{M})$, F/I indicate forskolin plus IBMX. Insulin released was normalized to total insulin content. (D) Average of area under curves (AUC) of insulin levels during islet perifusion from $\mathrm{C}(n=4)$. The first phase (Ph1) of insulin secretion at $16.7 \mathrm{mmol} / \mathrm{l}$ glucose was quantified from 20 to $35 \mathrm{~min}$ and the second phase (Ph2) from 35 to $60 \mathrm{~min}$ from C. Data shown are mean \pm s.E.M., $* P<0 \cdot 05$ compared with GFP control.

\section{Influence of $\mathrm{I}_{h}$ on membrane input resistance $\left(\mathrm{R}_{i n}\right)$}

Membrane input resistance $\left(R_{\text {in }}\right)$ is an important parameter of the intrinsic membrane properties, which determines membrane voltage responses to input currents (i.e. the currents flowing across the membrane). In general, the membrane voltage response is more sensitive to input current when $R_{\text {in }}$ is high. It has been shown that $I_{\mathrm{h}}$ participates in regulation of $R_{\text {in }}$ and thereby cell excitability in neurons (Magee 1998, Poolos et al. 2002, 2006). To assess if $I_{\mathrm{h}}$ influences $R_{\text {in }}$ in rat $\beta$-cells, we measured voltage responses to a set of injected hyperpolarizing currents under currentclamp mode. As shown in GFP-transduced cells, hyperpolarizing current produced a depolarizing voltage sag (or inflexion) (Fig. 8Aii, indicated by dashed arrow); this voltage sag reflected the activation of $I_{\mathrm{h}}$ that depolarizes the membrane potential. Compared to GFP control, the hyperpolarizing current resulted in a more significant depolarizing sag in HCN2-transduced cells because of the enhanced $I_{\mathrm{h}}$ (Fig. 8Aiii). Figure $8 \mathrm{~B}$ shows that the mean $R_{\text {in }}$ (calculated from -20 to $-60 \mathrm{pA}$ of injected currents) was lower in HCN2 (from $935 \pm 115 \mathrm{M} \Omega$ to $548 \pm 54 \mathrm{M} \Omega, n=7$, $P<0.05$ versus control) than that in GFP control cells (from $1375 \pm 159$ to $998 \pm 88 \mathrm{M} \Omega, n=8)$; in contrast, the mean $R_{\text {in }}$ of HCN2-AYA ranged from $2179 \pm 306$ to $1540 \pm 100 \mathrm{M} \Omega$ being substantially higher $(n=6, P<0 \cdot 05$ versus control).
Since $I_{\mathrm{h}}$ has been reported to limit membrane potential from increased hyperpolarization in neurons (Poolos et al. 2002), we thus tested if this occurs in rat $\beta$-cells. As seen (Fig. 8 Aii-iv), the difference between voltages induced by -20 and $-140 \mathrm{pA}$ injected currents $\left(\Delta V=V_{-20 \mathrm{pA}}-V_{-140 \mathrm{pA}}\right)$ was calculated. We found HCN2 over-expression significantly decreased $\Delta V$ compared to GFP control $(26 \pm 4 \mathrm{mV}$ for HCN2 overexpression, $n=7 ; 67 \pm 6 \mathrm{mV}$ for GFP control, $n=6 ; P<0 \cdot 001$, Fig. $8 \mathrm{C})$, suggesting that $I_{\mathrm{h}}$ can prevent membrane potential from hyperpolarization in $\beta$-cells.

\section{Influence of $\mathrm{I}_{h}$ on membrane hyperpolarization}

We therefore next examined whether HCN channel modulation can affect the natural membrane potential responses. Membrane potential recordings from whole rat islets were performed in standard extracellular solution containing $5.6 \mathrm{mmol} / 1 \mathrm{KCl}$. Figure 1 shows membrane potential responses at 11.1 and $2.8 \mathrm{mmol} / \mathrm{l}$ glucose concentrations in GFP(Fig. 1A) or HCN2-AYA-transduced islets (Fig. 1B). It is showed that dominant-negative HCN2-AYA did not cause significant change of the mean membrane potentials at low or high glucose concentrations compared with GFP control $(-41 \pm 3 \mathrm{mV}$ at $11.1 \mathrm{mmol} / \mathrm{l}$ glucose and $-61 \pm 2 \mathrm{mV}$ at
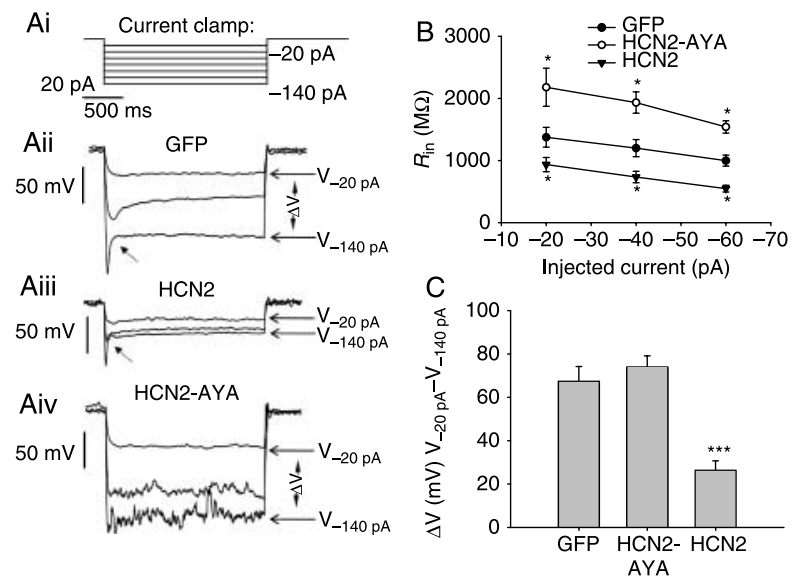

Figure 8 Influence of $I_{\mathrm{h}}$ on input resistance $\left(R_{\mathrm{in}}\right)$ : (Ai) stimulus protocol under current-clamp mode, resting potential was held at $-40 \mathrm{mV}$ by injecting constant current. The voltage responses were induced by additional hyperpolarizing currents ranging from -20 to $-140 \mathrm{pA}$ with a $20 \mathrm{pA}$ increment. Representative current-clamp recordings in response to injected hyperpolarizing currents in rat $\beta$-cells transduced with GFP (Aii), HCN2 (Aiii) or HCN2-AYA (Aiv) are shown. For clarity, only voltages induced by $-20,-60$ and $-140 \mathrm{pA}$ injected currents are included. The dashed arrow indicated depolarizing 'sag'. (B) Summary of input resistance obtained by the average of the voltage responded to a set of injected hyperpolarizing currents. (C) Group data for the difference between the two voltages in response to -20 and $-140 \mathrm{pA}$ of injected currents $\left(\Delta V=V_{-20 \mathrm{pA}}-V_{-140 \mathrm{pA}}\right)$ showing the stabilizing effect of $I_{\mathrm{h}}$ on membrane potential. Data shown are means \pm S.E.M., ${ }^{*} P<0.05$ and ${ }^{* * *} P<0 \cdot 001$, respectively, compared with the control. 
$2.8 \mathrm{mmol} / \mathrm{l}$ glucose for HCN2-AYA, $n=5$; vs $-41 \pm 2 \mathrm{mV}$ at $11.1 \mathrm{mmol} / 1$ glucose and $-55 \pm 4 \mathrm{mV}$ at $2.8 \mathrm{mmol} / 1$ glucose for GFP control, $n=5, P>0 \cdot 05$; Fig. 1C).

We then tested the membrane potential responses from non-adenovirus-infected islets in extracellular solution containing low potassium $(2.5 \mathrm{mmol} / \mathrm{l} \mathrm{KCl})$ and $11.1 \mathrm{mmol} / 1$ glucose. As shown in Fig. 2, $\mathrm{K}_{\mathrm{ATP}}$ channel opener diazoxide $(200 \mu \mathrm{M})$ evoked remarkable hyperpolarization $(-77 \pm 5 \mathrm{mV})$, application of ZD7288 $(50 \mu \mathrm{M})$ caused further hyperpolarization $(-84 \pm 4 \mathrm{mV})$ which could be reversed by $\mathrm{K}_{\mathrm{ATP}}$ channel blocker, tolbutamide $(300 \mu \mathrm{M})$. In average, ZD7288 caused $17 \%$ increased hyperpolarization compared to the membrane potential change induced by diazoxide (Fig. 2B).

\section{Influence of $\mathrm{I}_{h}$ on insulin secretion in extracellular solution containing $2.5 \mathrm{mmol} / \mathrm{l} \mathrm{KCl}$}

Using islet perifusion, we examined biphasic glucosestimulated insulin secretion in islets at low potassium conditions. At $2.8 \mathrm{mmol} / 1$ glucose, no difference was observed between HCN2-AYA and GFP groups $(3 \cdot 6 \pm 0 \cdot 5$ vs $3 \cdot 7 \pm 0 \cdot 2$, Fig. 3) as quantified by area under the curve analysis. At $16.7 \mathrm{mmol} / 1$ glucose, islets treated with HCN2-AYA displayed a similar level of insulin secretion in the first phase, and a markedly lower level in the second phase compared with GFP control $(52.6 \pm 1.9$ vs $63 \cdot 7 \pm 3 \cdot 2$, Fig. 3).

\section{Discussion}

We have recently demonstrated the presence of $\mathrm{HCN}$ channels in mouse and rat pancreatic $\beta$-cells (El Kholy et al. 2007), whereas their functions are still unclear. We and others found that the HCN channel antagonist, ZD7288, has a $I_{\mathrm{h}^{-}}$ independent inhibitory effect on exocytosis, and the three other HCN channel antagonists, caesium, cilobradine, zatebradine lead to suppression of $\mathrm{Kv}$ channels (Paolisso et al. 1985, Satoh \& Yamada 2002, Gonzalez-Iglesias et al. 2006, El Kholy et al. 2007). These $I_{\mathrm{h}}$-independent effects hampered use of these reagents in some functional studies. To circumvent these problems, in the present study, we investigated the functional characterization of $\mathrm{HCN}$ channels by manipulating $\mathrm{HCN}$ channel expression genetically in primary $\beta$-cells.

Our voltage-clamp data clearly show that over-expression of HCN2 can effectively enhance $I_{\mathrm{h}}$, and over-expression of HCN2-AYA almost completely suppresses $I_{\mathrm{h}}$. It has been proposed that different $\mathrm{HCN}$ isoforms could co-assemble to form heteromers of HCN channels (Chen et al. 2001, Whitaker et al. 2007). Some evidence from studies using dominant-negative strategies has confirmed this notion. For example, in the neonatal ventricle, HCN2-AYA almost completely suppressed the native current mainly encoded by HCN2 and HCN4 in a dominant-negative manner (Er et al.
2003). It is also reported that a dominant-negative HCN2 pore mutant was able to suppress both HCN2 and HCN1 wild-type channels (Xue et al. 2002). Here, the fact that HCN2-AYA almost completely blocked native $I_{\mathrm{h}}$ in rat $\beta$-cells (where four $\mathrm{HCN}$ isoforms are present), indicates different $\mathrm{HCN}$ isoforms can co-assemble to form heteromeric channel complexes in pancreatic $\beta$-cells.

In the current-clamp experiments, our results reveal that suppression of $I_{\mathrm{h}}$ significantly enhanced membrane input resistance $\left(R_{\mathrm{in}}\right)$, while over-expression of $I_{\mathrm{h}}$ reduced $R_{\mathrm{in}}$, indicating that $I_{\mathrm{h}}$ is a regulator in determining $R_{\text {in }}$ in pancreatic $\beta$-cells. $R_{\text {in }}$ is an important parameter of the intrinsic membrane properties. According to Ohm's law $\left(V=I R_{\text {in }}\right)$, modulation of $R_{\text {in }}$ will adjust the response of cell membrane potential $(V)$ to the input current stimulus $(I)$. Thus, our finding suggests that $I_{\mathrm{h}}$ may play a role to modulate $\beta$-cell membrane potential responses by modulating $R_{\text {in }}$. Of note, besides the traditional voltage- and time-dependent component of HCN current, various studies suggest there also is an instantaneous, or voltage-independent, component $\left(I_{\text {inst }}\right)$ of HCN currents that may represent ion flow through a 'leaky' channel (Proenza et al. 2002, Proenza \& Yellen 2006). Therefore, both components may contribute to the effect of HCN channels on $R_{\mathrm{in}}$, and this may explain the observation that there were differences in input resistance between groups during injection of $-20 \mathrm{pA}$ current (Fig. 8B), where the corresponding voltage is positive to the threshold for activation of the time-dependent component of $\mathrm{HCN}$ currents (around -70 to $-80 \mathrm{mV}$ ).

HCN current is reported to function as a safety inward current that helps prevent the membrane from hyperpolarization so that the cell membrane potential is maintained at appropriate levels (Williams et al. 2002). However, our data show that suppression of $I_{\mathrm{h}}$ did not significantly affect membrane potential at either low or high glucose in standard extracellular solution containing $5.6 \mathrm{mmol} / 1 \mathrm{KCl}$ (Fig. 1), indicating the native $I_{\mathrm{h}}$ may not be sufficient to influence the islet cell membrane potential at the conditions tested. We then examined the effect of $I_{\mathrm{h}}$ on membrane hyperpolarization in a low potassium extracellular solution $\left(\left[\mathrm{K}^{+}\right]_{\mathrm{o}}\right)$, because theoretically, decrease of the $\left[\mathrm{K}^{+}\right]_{\mathrm{o}}$ could shift the cell resting potential to a more hyperpolarized voltage, where HCN channels are in a more activated state. Indeed, under low $\left[\mathrm{K}^{+}\right]_{\mathrm{o}}$ conditions, blockade of $I_{\mathrm{h}}$ by ZD7288 induced an increased membrane hyperpolarization. The effect of ZD7288 on membrane potential was unlikely due to effects on other channels, because we find that ZD7288 has no effects on voltage-dependent potassium channels, calcium channels and $\mathrm{K}_{\text {ATP }}$ channels (El Kholy 2007). The results therefore indicate that $I_{\mathrm{h}}$ in $\beta$-cells possess the potential to counteract membrane over-hyperpolarization at least under low $\left[\mathrm{K}^{+}\right]_{\mathrm{o}}$ conditions.

Our previous report suggests that knock-down of HCN channel protein by siRNA does not influence insulin secretion under normal $\mathrm{K}^{+}$conditions in insulinoma MIN6 cells (El Kholy et al. 2007). In the present study, we 
have verified the results by dominant-negative suppression of HCN channels using HCN2-AYA in rat islets. Our data demonstrate suppression of $I_{\mathrm{h}}$ did not affect insulin secretion and application of forskolin/IBMX to increase intracellular cAMP could not change the influence of $I_{\mathrm{h}}$ on insulin secretion at standard extracellular $\mathrm{K}^{+}$concentrations (Fig. 7), suggesting $I_{\mathrm{h}}$ is not sufficient to modulate insulin release under normal $\left[\mathrm{K}^{+}\right]_{\mathrm{o}}$ conditions.

Under low $\left[\mathrm{K}^{+}\right]_{\mathrm{o}}$ conditions, however, a higher level of insulin secretion (especially for the second phase) was observed in control group at $16.7 \mathrm{mmol} / 1$ glucose but not at $2.8 \mathrm{mmol} / 1$ glucose in comparison with HCN2-AYA (Fig. 3), suggesting that HCN channels can facilitate glucoseinduced insulin secretion under the conditions tested. This phenomenon is probably due to the activation of $\mathrm{HCN}$ channels rendered by the preceding low glucose, low $\left[\mathrm{K}^{+}\right]_{\mathrm{o}}$ conditions (where HCN channels in $\beta$-cells are in a more activated state compared with normal $\left[\mathrm{K}^{+}\right]_{\mathrm{o}}$ conditions), because studies have revealed that activation of $\mathrm{HCN}$ channels can also lead to enhancement of subsequent stimulus-induced synaptic transmission in dorsal root ganglion neurons (Yu et al. 2004) and crayfish (Beaumont \& Zucker 2000, Beaumont et al. 2002). The mechanism of HCN channel modulation of exocytosis remains to be elucidated, but two possibilities have been raised: 1) fractional $\mathrm{Ca}^{2+}$ influx and accumulation through HCN channels (Yu et al. 2004), 2) the involvement of actin cytoskeletion in the interaction between HCN channels and exocytotic machinery (Beaumont \& Zucker 2000, Beaumont et al. 2002, Zhong \& Zucker 2004). Further studies are needed to clarify the involved mechanisms. Nevertheless, in the case of $I_{\mathrm{h}}$ in $\beta$-cells, our results suggest a potential role for HCN channels in regulating insulin secretion under low $\left[\mathrm{K}^{+}\right]_{\mathrm{o}}$ conditions.

It is worth pointing out that hypokalemia (i.e. serum $\mathrm{K}^{+}$ concentration $<3.6 \mathrm{mmol} / \mathrm{l}$ ) is thought to be the most common electrolyte abnormality encountered in clinical practice, and is found in over $20 \%$ of hospitalized patients (Gennari 1998). In diabetes mellitus, hypokalemia often develops, particular in patients with diabetic ketoacidosis (Gennari 1998). Thus, it is likely that $I_{\mathrm{h}}$ in $\beta$-cells may play a protective role under these pathophysiological conditions.

\section{Declaration of interest}

The authors declare that there is no conflict of interest that would prejudice the impartiality of this scientific work.

\section{Funding}

The majority of this work was supported by operating grants from the Canadian Institutes of Health Research to M B W (MOP 49521).

Other contributions: Q W (MOP 79534) from CIHR, R B R (PPG HL28958) from NIH and H Y G from the Juvenile Diabetes Research Foundation (1-2005-1112). Q W was a Canadian Diabetes Association Scholar and is a recipient of a New Investigator Award from CIHR.

\section{Acknowledgements}

The authors thank C J Mahowald and Y C Huang (University of Toronto, Canada) for assistance with manuscript preparation.

\section{References}

Accili EA, Proenza C, Baruscotti M \& DiFrancesco D 2002 From funny current to HCN channels: 20 years of excitation. News in Physiological Sciences 17 32-37.

Beaumont V \& Zucker RS 2000 Enhancement of synaptic transmission by cyclic AMP modulation of presynaptic $I_{\mathrm{h}}$ channels. Nature Neuroscience 3 133-141.

Beaumont V, Zhong N, Froemke RC, Ball RW \& Zucker RS 2002 Temporal synaptic tagging by $I(\mathrm{~h})$ activation and actin: involvement in long-term facilitation and cAMP-induced synaptic enhancement. Neuron 33 601-613.

Chen S, Wang J \& Siegelbaum SA 2001 Properties of hyperpolarizationactivated pacemaker current defined by coassembly of HCN1 and HCN2 subunits and basal modulation by cyclic nucleotide. Journal of General Physiology 117 491-504.

Dai FF, Zhang Y, Kang Y, Wang Q, Gaisano HY, Braunewell KH, Chan CB \& Wheeler MB 2006 The neuronal $\mathrm{Ca}^{2+}$ sensor protein visinin-like protein1 is expressed in pancreatic islets and regulates insulin secretion. Journal of Biological Chemistry 281 21942-21953.

DiFrancesco D 1993 Pacemaker mechanisms in cardiac tissue. Annual Review of Physiology $\mathbf{5 5}$ 455-472.

Er F, Larbig R, Ludwig A, Biel M, Hofmann F, Beuckelmann DJ \& Hoppe UC 2003 Dominant-negative suppression of HCN channels markedly reduces the native pacemaker current $I(\mathrm{f})$ and undermines spontaneous beating of neonatal cardiomyocytes. Circulation 107 485-489.

Gennari FJ 1998 Hypokalemia. New England Journal of Medicine 339 451-458.

Gonzalez-Iglesias AE, Kretschmannova K, Tomic M \& Stojilkovic SS 2006 ZD7288 inhibits exocytosis in an HCN-independent manner and downstream of voltage-gated calcium influx in pituitary lactotrophs. Biochemical and Biophysical Research Communications 346 845-850.

Kaupp UB \& Seifert R 2001 Molecular diversity of pacemaker ion channels. Annual Review of Physiology 63 235-257.

El Kholy W 2007 The role of hyperpolarization activated cyclic nucleotide modulated and voltage gated potassium channels in pancreatic beta-cell function. University of Toronto.

El Kholy W, MacDonald PE, Fox JM, Bhattacharjee A, Xue T, Gao X, Zhang Y, Stieber J, Li RA, Tsushima RG et al. 2007 Hyperpolarization-activated cyclic nucleotide-gated channels in pancreatic beta-cells. Molecular Endocrinology 21 753-764.

Koizumi A, Jakobs TC \& Masland RH 2004 Inward rectifying currents stabilize the membrane potential in dendrites of mouse amacrine cells: patch-clamp recordings and single-cell RT-PCR. Molecular Vision 10 328-340.

Ludwig A, Zong X, Jeglitsch M, Hofmann F \& Biel M 1998 A family of hyperpolarization-activated mammalian cation channels. Nature 393 587-591.

Ludwig A, Zong X, Stieber J, Hullin R, Hofmann F \& Biel M 1999 Two pacemaker channels from human heart with profoundly different activation kinetics. EMBO Journal 18 2323-2329.

MacDonald PE \& Wheeler MB 2003 Voltage-dependent $\mathrm{K}(+)$ channels in pancreatic beta cells: role, regulation and potential as therapeutic targets. Diabetologia 46 1046-1062.

MacDonald PE, Ha XF, Wang J, Smukler SR, Sun AM, Gaisano HY, Salapatek AM, Backx PH \& Wheeler MB 2001 Members of the Kv1 and $\mathrm{Kv} 2$ voltage-dependent $\mathrm{K}(+)$ channel families regulate insulin secretion. Molecular Endocrinology 15 1423-1435.

MacDonald PE, Sewing S, Wang J, Joseph JW, Smukler SR, Sakellaropoulos G, Wang J, Saleh MC, Chan CB, Tsushima RG et al. 2002 Inhibition of $\mathrm{Kv} 2.1$ voltage-dependent $\mathrm{K}^{+}$channels in pancreatic beta-cells enhances glucose-dependent insulin secretion. Journal of Biological Chemistry 277 44938-44945. 
Magee JC 1998 Dendritic hyperpolarization-activated currents modify the integrative properties of hippocampal CA1 pyramidal neurons. Journal of Neuroscience 18 7613-7624.

Manning Fox JE, Gyulkhandanyan AV, Satin LS \& Wheeler MB 2006 Oscillatory membrane potential response to glucose in islet beta-cells: a comparison of islet-cell electrical activity in mouse and rat. Endocrinology $1474655-4663$.

Meuth SG, Kanyshkova T, Meuth P, Landgraf P, Munsch T, Ludwig A, Hofmann F, Pape HC \& Budde T 2006 Membrane resting potential of thalamocortical relay neurons is shaped by the interaction among TASK3 and HCN2 channels. Journal of Neurophysiology 96 1517-1529.

Paolisso G, Nenquin M, Meissner HP \& Henquin JC 1985 The effects of cesium chloride on insulin release, ionic fluxes and membrane potential in pancreatic B-cells. Biochimica et Biophysica Acta 844 200-208.

Pape HC 1996 Queer current and pacemaker: the hyperpolarization-activated cation current in neurons. Annual Review of Physiology 58 299-327.

Poolos NP, Migliore M \& Johnston D 2002 Pharmacological upregulation of h-channels reduces the excitability of pyramidal neuron dendrites. Nature Neuroscience $\mathbf{5} 767-774$.

Poolos NP, Bullis JB \& Roth MK 2006 Modulation of h-channels in hippocampal pyramidal neurons by $\mathrm{p} 38$ mitogen-activated protein kinase. Journal of Neuroscience 26 7995-8003.

Proenza C \& Yellen G 2006 Distinct populations of HCN pacemaker channels produce voltage-dependent and voltage-independent currents. Journal of General Physiology 127 183-190.

Proenza C, Angoli D, Agranovich E, Macri V \& Accili EA 2002 Pacemaker channels produce an instantaneous current. Journal of Biological Chemistry 277 5101-5109.

Qu J, Barbuti A, Protas L, Santoro B, Cohen IS \& Robinson RB 2001 HCN2 overexpression in newborn and adult ventricular myocytes: distinct effects on gating and excitability. Circulation Research 89 E8-E14.

Robinson RB \& Siegelbaum SA 2003 Hyperpolarization-activated cation currents: from molecules to physiological function. Annual Review of Physiology 65 453-480.

Rorsman P, Bokvist K, Ammala C, Eliasson L, Renstrom E \& Gabel J 1994 Ion channels, electrical activity and insulin secretion. Diabète \& Métabolisme 20 138-145.

Santoro B, Grant SG, Bartsch D \& Kandel ER 1997 Interactive cloning with the $\mathrm{SH} 3$ domain of $\mathrm{N}$-src identifies a new brain specific ion channel protein, with homology to eag and cyclic nucleotide-gated channels. PNAS 94 14815-14820.

Santoro B, Liu DT, Yao H, Bartsch D, Kandel ER, Siegelbaum SA \& Tibbs GR 1998 Identification of a gene encoding a hyperpolarization-activated pacemaker channel of brain. Cell 93 717-729.

Satoh TO \& Yamada M 2002 Multiple inhibitory effects of zatebradine (ULFS 49) on the electrophysiological properties of retinal rod photoreceptors. Pflügers Archiv: European Journal of Physiology 443 532-540.
Targonsky ED, Dai F, Koshkin V, Karaman GT, Gyulkhandanyan AV, Zhang Y, Chan CB \& Wheeler MB 2006 Alpha-lipoic acid regulates AMP-activated protein kinase and inhibits insulin secretion from beta cells. Diabetologia 49 $1587-1598$.

Tian L \& Shipston MJ 2000 Characterization of hyperpolarization-activated cation currents in mouse anterior pituitary, AtT20 D16:16 corticotropes. Endocrinology 141 2930-2937.

Wahl-Schott C \& Biel M 2009 HCN channels: structure, cellular regulation and physiological function. Cellular and Molecular Life Sciences 66 470-494.

Wendt A, Birnir B, Buschard K, Gromada J, Salehi A, Sewing S, Rorsman P \& Braun M 2004 Glucose inhibition of glucagon secretion from rat alpha-cells is mediated by GABA released from neighboring beta-cells. Diabetes $\mathbf{5 3}$ 1038-1045.

Whitaker GM, Angoli D, Nazzari H, Shigemoto R \& Accili EA 2007 HCN2 and $\mathrm{HCN} 4$ isoforms self-assemble and co-assemble with equal preference to form functional pacemaker channels. Journal of Biological Chemistry 282 22900-22909.

Williams SR, Christensen SR, Stuart GJ \& Hausser M 2002 Membrane potential bistability is controlled by the hyperpolarization-activated current $I(\mathrm{H})$ in rat cerebellar Purkinje neurons in vitro. Journal of Physiology 539 469-483.

Xiao J, Nguyen TV, Ngui K, Strijbos PJ, Selmer IS, Neylon CB \& Furness JB 2004 Molecular and functional analysis of hyperpolarisation-activated nucleotide-gated (HCN) channels in the enteric nervous system. Neuroscience 129 603-614.

Xue T, Marban E \& Li RA 2002 Dominant-negative suppression of. Circulation Research 90 1267-1273.

Yagi J \& Sumino R 1998 Inhibition of a hyperpolarization-activated current by clonidine in rat dorsal root ganglion neurons. Journal of Neurophysiology 80 1094-1104.

Yu X, Duan KL, Shang CF, Yu HG \& Zhou Z 2004 Calcium influx through hyperpolarization-activated cation channels $(I(\mathrm{~h})$ channels) contributes to activity-evoked neuronal secretion. PNAS 101 1051-1056.

Zhang Y, Zhang N, Gyulkhandanyan AV, Xu E, Gaisano HY, Wheeler MB \& Wang Q 2008 Presence of functional hyperpolarisation-activated cyclic nucleotide-gated channels in clonal alpha cell lines and rat islet alpha cells. Diabetologia 51 2290-2298.

Zhong N \& Zucker RS 2004 Roles of $\mathrm{Ca}^{2+}$, hyperpolarization and cyclic nucleotide-activated channel activation, and actin in temporal synaptic tagging. Journal of Neuroscience 24 4205-4212.

Received in final form 29 July 2009

Accepted 4 August 2009

Made available online as an Accepted Preprint 4 August 2009 